\title{
Public opinion on the eligibility of health care for migrants and refugees in Slovenia
}

\author{
Maruša Kolar, ${ }^{1}$ Igor Lukšič̌ ${ }^{1}$ and Branko Gabrovec ${ }^{2}$
}

${ }^{1}$ Faculty of Social Sciences, University of Ljubljana, Ljubljana, Slovenia. ${ }^{2}$ National Institute of Public Health, Ljubljana, Slovenia (Correspondence to: Branko Gabrovec: branko.gabrovec@nijz.si).

\begin{abstract}
Background: Worldwide, more than 200 million people have left their home country, and international migration from the Middle East to Europe is increasing. The journey and the poor living conditions cause numerous health problems. Migrants show significant differences in lifestyle, health beliefs and risk factors compared with native populations and this can impact access to health systems and participation in prevention programmes.

Aims: Our aim was to measure the attitude of survey participants to migrants and to define up to what level migrants are entitled to health care from the viewpoint of Slovenian citizens.

Methods: This survey was carried out in January 2019 and included 311 respondents. We applied a quantitative, nonexperimental sampling method. We used a structured survey questionnaire based on an overview, a national survey on the experiences of patients in hospitals and user satisfaction with medical services of basic health care at the primary level.

Results: A large proportion of the respondents agreed that migrants should receive emergency or full health care provision, that there is no need to limit their health rights and that they do not feel that their own rights are compromised by the rights of migrants. Over $80 \%$ agreed with health protection for women and for children.

Conclusion: The findings offer a basis for supplementing the existing, or designing a new, model of health care provision for migrants in Slovenia, focusing on the provision of health protection and care as a fundamental human right.

Keywords: delivery of health care, health care sectors, refugees, transients, migrants

Citation: Kolar N; Lukšič I; Gabrovec B. Public opinion on the eligibility of health care for migrants and refugees in Slovenia. East Mediterr Health J. 2021;27(12):1182-1188. https://doi.org/10.26719/emhj.21.063

Received: 21/12/20; accepted: 15/06/21

Copyright (C) World Health Organization (WHO) 2021. Open Access. Some rights reserved. This work is available under the CC BY-NC-SA 3.0 IGO license (https://creativecommons.org/licenses/by-nc-sa/3.o/igo).
\end{abstract}

\section{Introduction}

Worldwide, more than 214 million people have left their country of origin (1), and international migration from the Middle East to all of Europe is increasing $(2,3)$. Over the last 3 years, an unprecedented flow of migrants has arrived in Europe (4). The number of migrants and refugees in Europe in the past few years has increased dramatically due to war, violence or persecution in their homeland (5).

Arduous journeys and poor living conditions are causing myriad health problems, and access to basic health care is extremely limited for those on the move. People are suffering at every stage of the journey, including after they settle in Europe (3).

The 2015-2017 global migratory crisis saw unprecedented numbers on the move and tremendous diversity in terms of age, sex and medical requirements (6). These high rates of net migration increased the pressure on health care services (2). Migrants show substantial differences in lifestyle, health beliefs and risk factors compared with the native populations. This can have a significant impact on migrants' access to health systems and participation in prevention programmes (7).

Migration may affect physical, mental (8) and social health (9). In addition to communicable diseases, such as respiratory, gastrointestinal and dermatologic infections, noncommunicable diseases, including chronic conditions and mental and social problems, account for a significant morbidity burden in newly arrived migrants and refugees. Vaccine-preventable diseases are also of the utmost importance (5). There is evidence that vaccine-preventable diseases have caused outbreaks in migrant holding centres. These outbreaks can be exacerbated by a combination of factors, including low immunization coverage, bad conditions that migrants face during their exhausting journey and overcrowding within holding facilities (4). In many countries, including Germany, newly arriving refugees face specific entitlement restrictions and access barriers to health care (10).

The current migration flow into Europe is leading to a growing ethnically diverse population in many countries. Now in particular, those populations have different health care needs, languages, traditions and previous levels of care. This higher level of diversity is likely to increase health inequalities and this might challenge health care systems if not addressed (11).

Although migrants have the right to health care under legal settlements issued by the European Union (EU), there is no standard European approach to offering health care since policies in each Member State are developed according to the specific migrant experience, 
political climate and attitudes towards migration (12). The appropriate management of the health problems of newly arrived refugees and migrants is affected by barriers to health care, including legal, communication, cultural and bureaucratic difficulties (5).

Compared to their counterparts from the EU, migrants generally face greater health problems and major barriers accessing health care. Consequently, migrant health policies should focus on protecting this vulnerable group, especially during economic hardship, taking into account economic and sociodemographic risk factors (12).

The positive trends in public support for development aid are encouraging in an age where economic hardships at home as well as the tone of national political discourse and rising right-wing populism appear to suggest otherwise (13).

In recent years, cross-border migration has gained significant attention in high-level policy dialogues in numerous countries (14), however health policy is still dependent on the general policies and public opinion of the country, which are in many cases anti-immigrant oriented.

While we know that anti-immigrant attitudes are widely expressed in public opinion and through parties aiming to limit immigration and migrant rights within European countries, we know less about the effects of such contextual hostility on immigrants, the targeted group (15).

In the case of Slovenia, the smallest country in central Europe, the majority of immigrants leave before they receive a residence permit. This means that refugees are not interested in staying in the country permanently for them it is only a transit zone. Due to the prolonged economic crisis and lack of financial resources and also the fact that the police, the army, civil defence and the Red Cross were not adequately prepared to deal with the situation, Slovenia found itself facing some serious problems associated with the large numbers of refugees coming to the country (16).

Public opinion on the introduction of new ethnic cultures into society, the settlement of migrants in Slovenian cities and homes, the provision of benefits to migrants and the allocation of quotas for receiving refugees was found to be equally divided (16). However, the main opposition political party spearheaded the securitization of migrations with a discourse based on selective information, simplification and exaggeration. Data from the survey showed that this had influenced public opinion (17).

The results of our survey indicate that respondents are mainly in favour of providing health protection as a fundamental human right for refugees and migrants. With regard to the measurement of public opinion from the special Eurobarometer, all results may be taken with a certain amount of reserve since just $42 \%$ of respondents believe that they are very well or fairly well informed about issues related to immigrants and integration (18). In the measurement of public opinion in the $\mathrm{EU}$ in 2018, the inhabitants of Slovenia placed immigration among the most significant challenges (58\%) (19).

Human rights are rights inherent to all human beings, whatever their nationality, place of residence, sex, national or ethnic origin, colour, religion, language or any other status. We are all equally entitled to our human rights without discrimination. These rights are all interrelated, interdependent and indivisible (20). As access to the most basic human rights includes access to health care, and health is the most important value in many surveys in Slovenia as well as in other countries, this might be a mechanism to influence public opinion regarding migration.

The aim of this study was to measure the attitudes of survey participants to migration and what level of health care for migrants is justifiable. In our research, we focused on 3 hypotheses:

- H1: respondents are of the opinion that it is not necessary to restrict their health rights and that they are not curtailed at the expense of migrants' rights;

- $\mathrm{H} 2$ : the quality of health conditions in individual areas of health care is related to the quality of the health system in Slovenia;

- H3: study participants who fear that migrants will spread contagious diseases support their right to accessibility to health care.

\section{Methods}

\section{Research tool}

We applied a quantitative, non-experimental sampling method of research. The research tool used was a structured survey questionnaire.

Based on a review of the available literature on the methods used in sample design in similar surveys, we proposed a basic framework for sample design and the type of sampling for the population of randomly selected respondents in Slovenia. We used descriptive and inferential statistics. Data were collected using a questionnaire comprising mostly closed questions. We used SPSS, version 21.0, to analyse the data.

A structured survey questionnaire was designed based on an overview of past research (4,7,17,21-23) and a national survey on the experiences of patients in hospitals (22) and user satisfaction with medical services of basic health care at the primary level (23).

\section{Sample}

The research was carried out through an online survey. We invited the general population through social media and various patient and patient rights organizations to fill out the survey. The snowball method was used.

A total of 545 persons responded to the online survey questionnaire, and 311 of them completed the entire survey questionnaire. Estimation of the total number of individuals invited was not feasible as most of them were contacted through social networks. 


\section{Description of the tool}

The survey questionnaire included 47 questions and statements, divided into 5 segments: media coverage of the migrant situation (6 questions); migration (7 questions); migrations to Slovenia (4 questions); the health system in Slovenia and migrants' right to health care services (27 questions - 16 presented); and demographic data (4 questions). This research presents answers to the 4 th segment of questions (about the health system in Slovenia and migrants' right to health care services).

The questions included in the survey were tested on a sample of test respondents through the focus group session, which included 12 participants from different organisations and interest groups (Health Insurance Institute of Slovenia, Ministry of Health, National Retiree Organization, Representative of Patient Rights, National Institute of Public Health, Medical Faculty of Ljubljana, Faculty of Health Sciences at Maribor and Government Office for the Support and Integration of Migrants). Additionally, the questionnaire was tested on a group of 40 health care students. From the responses, we identified possible problems we faced in relation to the content of the questions. At the same time, we were assured about the clarity and accuracy of the questions. The survey questionnaire content was valid, with reliability of internal consistency satisfactory to very satisfactory (26) and Cronbach's $\alpha=0.79$.

\section{Course of the research and data processing description}

The survey was carried out from 6 to 9 January 2019. The tool used was 1KA, an open source application that provides an online survey service. It was carried out in line with the Helsinki Declaration: Ethical principles for medical research involving human subjects (25). The data were analysed with descriptive statistics, $\chi^{2}$ (hypothesis 1) and ANOVA (hypothesis 2). The data were processed using the statistical program SPSS, version 21.0, using a significance level of $P<0.05$.

\section{Ethics}

This study was conducted in accordance with the Code of Ethics for Nurses and Nurse Assistants and the Declaration of Helsinki.

\section{Results}

Our sample included 141 males (45.3\%) and 170 (54.7\%) females. Details of the demographic characteristics of the participants are presented in Table 1.

A total of $50.3 \%$ of those surveyed rate the health care system as good, $16.7 \%$ as very good and $14.2 \%$ as excellent. The health care system in Slovenia is rated as bad by $13.9 \%$ of respondents, and as very bad by $4.9 \%$ of respondents. Regarding migrants, $38.5 \%$ of those surveyed believe that migrants bring communicable diseases into our environment, while $20.1 \%$ did not know how to answer this. In answer to the question "Is it right for migrants to be entitled to health care?", $44.4 \%$ believe that they should

\begin{tabular}{|c|c|c|}
\hline Characteristic & No. & $\%$ \\
\hline \multicolumn{3}{|l|}{ Sex } \\
\hline Male & 141 & 45.3 \\
\hline Female & 170 & 54.7 \\
\hline \multicolumn{3}{|l|}{ Age (years) } \\
\hline$\leq 20$ & 66 & 21.2 \\
\hline $21-40$ & 112 & 36.0 \\
\hline $41-60$ & 123 & 39.0 \\
\hline$\geq 61$ & 10 & 3.2 \\
\hline \multicolumn{3}{|l|}{ Education level } \\
\hline Primary school & 31 & 9.9 \\
\hline Vocational or secondary school & 102 & 32.8 \\
\hline Higher or tertiary education & 99 & 31.8 \\
\hline Master's degree/doctorate & 51 & 16.4 \\
\hline
\end{tabular}

only be entitled to urgent care, $43.0 \%$ that they should be entitled to full health care provision, $10.8 \%$ believe that they should be entitled if they pay the costs themselves and $2.1 \%$ take the view that they should not be entitled to any assistance. A total of $29.6 \%$ of those surveyed believe that Slovenia should offer its own citizens more in the way of health care at the expense of limiting the rights of migrants. Just $12.7 \%$ believe that Slovenian citizens are deprived of their rights to health care due to migrants.

In the area of quality of services, just $8.1 \%$ of respondents believe that they will receive lower quality care in the health system due to migrants. Regarding the changed conditions for the provision of health services due to migrants, $37.7 \%$ of respondents believe that they will wait longer for examinations while $44.4 \%$ believe that their right to health care will remain uncompromised. On the health risks due to the greater influx of migrants, $33.1 \%$ fear the occurrence of new diseases, $31.0 \%$ the occurrence of communicable diseases and $24.6 \%$ problems associated with inadequate hygiene, etc.

As regards exercising the right to health care provision, just $26.3 \%$ believe that migrants do not take advantage of the right to health care while $73.3 \%$ feel that all or at least some do so.

Additional questions regarding the rights of migrants to health care are shown in Table 2. These questions were selected for the areas of migrant health care which are the same as those available to the residents of Slovenia, and thus cover primary, secondary and tertiary levels of care. They were selected for the purpose of determining the approval/disapproval of equal rights to basic health care for both residents of Slovenia and for migrants.

We focused on primary health care since it is the entry point for the transition to secondary and tertiary health care. Tertiary health care is provided in accordance with Slovenian legislation and is not problematic. The responses from those surveyed indicate a high level of agreement and empathy regarding migrants having access to health services and care. Particularly noteworthy 


\begin{tabular}{|c|c|c|c|c|c|c|}
\hline Question & No. & $\begin{array}{c}\text { Yes } \\
\%\end{array}$ & $\begin{array}{c}\text { No } \\
\%\end{array}$ & $\begin{array}{l}\text { Other } \\
\%\end{array}$ & $\begin{array}{l}\text { Mean } \\
\text { value }\end{array}$ & SD \\
\hline $\begin{array}{l}\text { Should migrants in collective centres be entitled to packages that include } \\
\text { personal hygiene accessories? }\end{array}$ & 288 & 75.3 & 7.6 & 17.1 & 1.42 & 0.77 \\
\hline $\begin{array}{l}\text { Should we include the right to choose one's own doctor in the provision } \\
\text { of health care for migrants? }\end{array}$ & 281 & 27.8 & 32.7 & 39.5 & 2.21 & 0.81 \\
\hline $\begin{array}{l}\text { Should we include the right to dental care in the provision of health care } \\
\text { for migrants? }\end{array}$ & 281 & 67.3 & 32.7 & - & 1.33 & 0.47 \\
\hline $\begin{array}{l}\text { Should we include the right of female migrants to gynaecological } \\
\text { examinations in the provision of health care for migrants? }\end{array}$ & 281 & 81.5 & 18.5 & - & 1.19 & 0.38 \\
\hline $\begin{array}{l}\text { Should we include the right of children of migrants to school health } \\
\text { examinations in the provision of health care for migrants? }\end{array}$ & 281 & 81.1 & 18.9 & - & 1.19 & 0.39 \\
\hline $\begin{array}{l}\text { Should we include the right of migrants to preventive examinations } \\
\text { in the provision of health care for migrants [ZORA (cervical cancer } \\
\text { screening programme); DORA (breast cancer screening programme); } \\
\text { SVIT (national screening and early detection programme for colorectal } \\
\text { cancer)]? }\end{array}$ & 281 & 59.1 & 40.6 & - & 1.41 & 0.49 \\
\hline $\begin{array}{l}\text { Should we include the right to free testing for sexually transmissible } \\
\text { diseases (e.g. HIV) in the provision of health care for migrants? }\end{array}$ & 217 & 77.2 & 22.8 & - & 1.23 & 0.42 \\
\hline
\end{tabular}

are attitudes to preventive and screening programmes and to the health of children (81.1\%) and women (81.5\%). On the negative side, the only prominent response is in regard to the possibility of choosing one's own doctor, to which just $27.8 \%$ agree.

We also checked the assertions of respondents in a one-sample $\chi^{2}$ test for verifying concordance, to determine how far the observed distribution of values of the variable match the hypothetical distribution. All the assertions were shown to be statistically significant.

On testing hypothesis $\mathrm{H} 1$ regarding the restriction of respondents' health care rights, we found a statistically significant link between the variables "due to migrants, have your rights as a Slovenian citizen to health care been compromised" and the "worse state of health of Slovenian citizens" $(P<0.001)$.

Similarly, we determined as statistically significant that according to the self-reported beliefs, the rights of Slovenian citizens to health care provision were not compromised due to migrants and they will not suffer worse health conditions due to migrants $(P<0.001)$.

When testing hypothesis $\mathrm{H} 2$, the analysis showed a significant connection between the level of the health care system (primary level - first contact with a physician, diagnosis, managing acute and chronical diseases; secondary level - specialist care in hospital; tertiary level - treatment of most severe conditions) and migrants' awareness of individual health care; $\mathrm{H}_{2}$ was rejected as the differences in quality of care were not dissimilar in all groups $(F=4.694, P=0.010)$.

Analysis of hypothesis $\mathrm{H}_{3}$ revealed that survey participants who feared the spread of contagious diseases supported the availability of basic and emergency care only (55.0\%). In contrast, among participants who did not have this fear, $56.8 \%$ supported full access to health care.
The $\chi^{2}$ test confirmed a weak significance level of $0.09(P<$ 0.05 ) between the variables. Hypothesis 3 was confirmed.

\section{Discussion}

Our findings imply that bringing to the forefront the provision of health protection and care as a fundamental human right could alter the opinion of citizens on immigration. For the most part the measurements of public opinion are tied to brief surveys. In the survey conducted by Medica et al. a total of $52 \%$ of respondents believed that immigration policies should be tightened, while $23 \%$ felt there was no need for any tightening (26). The proportion agreeing with tightening up asylum policy was somewhat lower in the survey by Potič and Pribošič, where $41 \%$ agreed with a tightening (27). A review of public opinion surveys conducted between 1990 and 2016 showed that in the 9os respondents were not more favourably disposed towards migrants and refugees who came from the republics of the former Yugoslavia than they are towards migrants and refugees today coming from non-European countries (28).

Our findings indicate that respondents are more in favour of providing health protection as a fundamental human right for refugees and migrants. As access to the most basic human rights includes access to health care, and health is the most important value in many surveys in all countries, this could be a mechanism for influencing public opinion regarding migration.

In our survey, the respondents rate the health care system in Slovenia as good to very good. In the survey by Zupanc Tergalv et al., the level of satisfaction is lower, specifically with a lower median value (2.86) on a scale of $1-5$ (29). That the health care system needs change is rated very highly (4.32). 
Our respondents assert (37.7\%) that, due to migrants and their need for health care and given the changed conditions, waiting times (for the respondents) would be longer. This is understandable since access to health services in Slovenia is limited because of the waiting times (30).

A large proportion of our survey responses (> 80\%) indicated the agreement of respondents for migrants to receive emergency or full health care provision: they are particularly sensitive in regard to the health protection of women and children. A high level of agreement was also found regarding the right to free testing for sexually transmissible diseases: around $75 \%$ of respondents feel that migrants in collective centres should be entitled to packages that include personal hygiene accessories. This high level of agreement has a probable link to the fear of new diseases, communicable diseases and inadequate hygiene. A high level of support for preventive health programmes (59.1\%) has been reported previously (31).

This study has some limitations. The first is the sample size $(n=311)$, and as the participants were invited to take part through social media, it is impossible to determine the response rate, which can affect external validity. The second limitation lies in the limited comparison with other surveys since there are practically none for the area of migration, refugees and health care.

\section{Conclusion}

In regard to refugees and migrants, in the majority of measured surveys public opinion is roughly divided. Access to health care is considered a fundamental human right. Our findings imply that bringing to the forefront the provision of health protection and care as a fundamental human right could alter survey respondents' opinion on immigration. The health care system is bound to provide health protection and care for all who need it. Our survey points to a high level of empathy and agree- ment with the right to the provision of health protection and care for refugees and migrants as well as citizens. Our findings therefore open up an important field for further research and for formulating policies and communication strategies, bringing to the forefront the provision of health protection and care as a fundamental human right.

The fundamental issue of further concrete actions is clearly linked to the question of how far migrants' rights to health care extend in terms of fundamental human rights. It should be emphasized that setting the boundaries is very difficult. When it comes to restrictions, we are encroaching on the field of fundamental human rights.

Public opinion on migrants' rights to health care also opens up a range of suggestions as to how the existing health care system can be improved and complemented in such a way as to satisfy the interests of both sets of stakeholders, i.e. providing migrants with basic health care while ensuring unchanged health care rights to the residents of Slovenia. Given that public opinion is not largely in favour of migration, but is in favour of providing health care to migrants, this aspect could help to shape public opinion through appropriate communication.

The challenge could be to establish a common network of migrant health care across the country with well-defined rules of action in different situations. For the time being, medical care is provided to migrants, although rather sporadically, based on the personal medical judgment of the staff.

Funding: This study was financed with internal funds. No sponsor played a role in the study design; in the collection, analysis and interpretation of data; in the writing of the report; or in the decision to submit the paper for publication.

Competing interests: None declared.

\section{Opinion publique sur l'admissibilité des migrants et des réfugiés pour les soins de santé en Slovénie \\ Résumé}

Contexte : Dans le monde, plus de 200 millions de personnes ont quitté leur pays d'origine, et les migrations internationales du Moyen-Orient vers l'Europe sont en augmentation. Le périple entrepris par ces personnes ainsi que leurs mauvaises conditions de vie causent de nombreux problèmes de santé. Les migrants présentent des différences significatives en termes de mode de vie, de croyances en matière de santé et de facteurs de risque par rapport aux populations autochtones, ce qui peut avoir un impact sur l'accès aux systèmes de santé et la participation aux programmes de prévention.

Objectifs : La présente enquête visait à mesurer l'attitude des participants vis-à-vis des migrants et à définir dans quelle mesure les migrants ont droit aux soins de santé du point de vue des citoyens slovènes.

Méthodes : Cette enquête a été réalisée en janvier 2019 auprès de 311 répondants. Nous avons appliqué une méthode d'échantillonnage quantitatif non expérimentale. Nous avons utilisé un questionnaire d'enquête structuré basé sur une vue d'ensemble, ainsi qu'une enquête nationale sur les expériences des patients dans les hôpitaux et sur la satisfaction des utilisateurs vis-à-vis des services de soins de santé de base au niveau primaire.

Résultats : Une grande partie des personnes interrogées ont convenu que les migrants devraient recevoir des soins de santé d'urgence ou complets et qu'il n'est pas nécessaire de limiter leurs droits en matière de santé, et ont 
indiqué ne pas avoir le sentiment que leurs propres droits sont compromis par ceux des migrants. Plus de $80 \%$ des répondants approuvaient l'idée d'une protection de la santé pour les femmes et les enfants.

Conclusion : Les résultats de l'enquête offrent une base pour compléter le modèle existant ou concevoir un nouveau modèle de prestation de soins de santé pour les migrants en Slovénie, avec pour axe principal l'accès à une protection de la santé et aux soins de santé en tant que droit humain fondamental.

$$
\begin{aligned}
& \text { الرأي العام بشأن أهلية المهاجرين واللاجئين للحصول على الرعاية الصحية في سلوفينيا }
\end{aligned}
$$

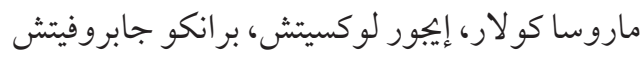

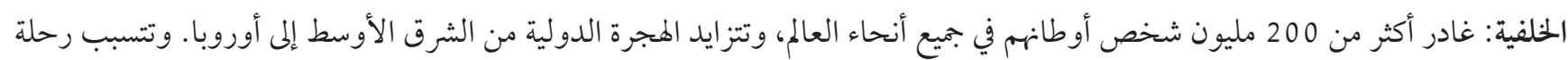

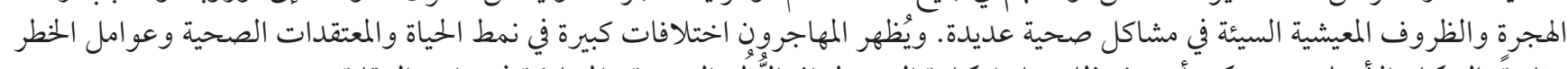

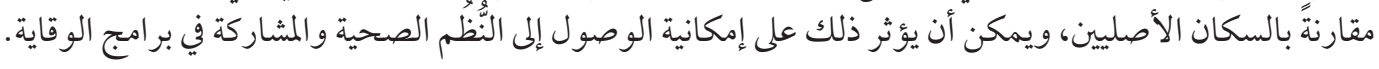

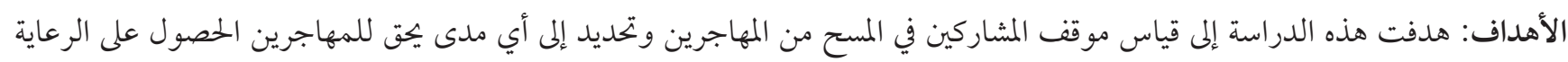
الصحية من وجهة نظر المواطنين السلوفينيين.

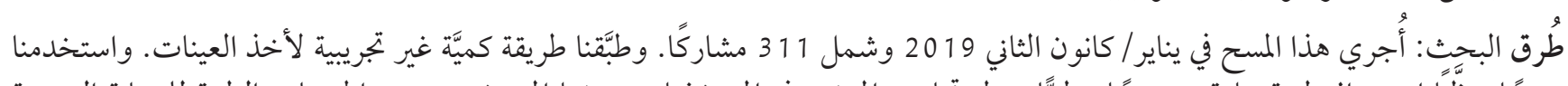

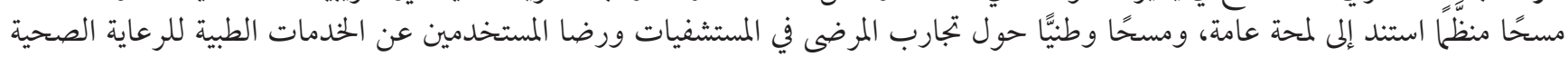
الأساسية في المستوى الأولي.

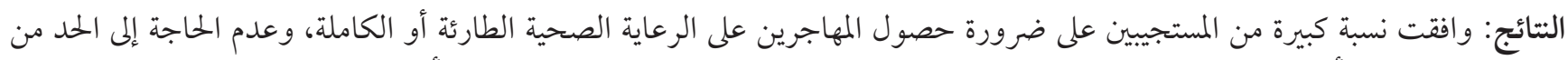

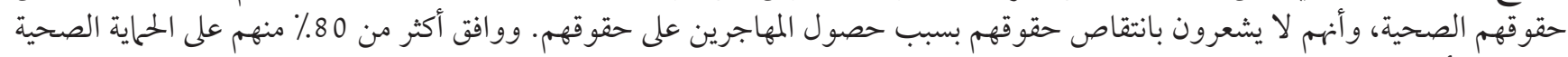
للنساء والأطفال.

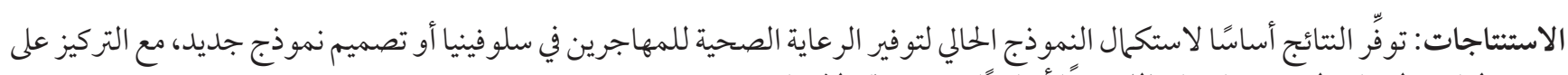

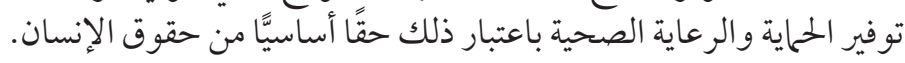

\section{References}

1. Luiking ML, Heckemann B, Ali P, Dekker-van Doorn C, Ghosh S, Kydd A, et al. Migrants' healthcare experience: a meta-ethnography review of the literature. J Nurs Scholarsh. 2019;51:58-67. doi:10.1111/jnu.12442.

2. Daynes L. The health impacts of the refugee crisis: a medical charity perspective. Clin Med (Lond). 2016;16:437-40. doi:10.7861/ clinmedicine.16-5-437.

3. Credé SH, Such E, Mason S. International migrants' use of emergency departments in Europe compared with non-migrants' use: a systematic review. Eur J Public Health. 2018;28:61-73. doi:10.1093/eurpub/ckxo57.

4. Giambi C, Del Manso M, Dalla Zuanna T, Riccardo F, Bella A, Caporali MG, et al. National immunization strategies targeting migrants in six European countries. Vaccine. 2019;37:4610-17. doi:10.1016/j.vaccine.2018.01.060.

5. Pavli A, Maltezou H. Health problems of newly arrived migrants and refugees in Europe. J Travel Med. 2017;24. doi:10.1093/jtm/ taxo16.

6. Abbas M, Aloudat T, Bartolomei J, Carballo M, Durieux-Paillard S, Gabus L, et al. Migrant and refugee populations: a public health and policy perspective on a continuing global crisis. Antimicrob Resist Infect Control. 2018;7:113. doi:10.1186/s13756-0180403-4.

7. Rosano A, Dauvrin M, Buttigieg SC, Ronda E, Tafforeau J, Dias S. Migrant's access to preventive health services in five EU countries. BMC Health Serv Res. 2017;17:588. doi:10.1186/s12913-017-2549-9.

8. Eleftherakos C, van den Boogaard W, Barry D, Severy N, Kotsioni I, Roland-Gosselin L. "I prefer dying fast than dying slowly", how institutional abuse worsens the mental health of stranded Syrian, Afghan and Congolese migrants on Lesbos island following the implementation of EU-Turkey deal. Confl Health. 2018;12:38. doi:10.1186/s13031-018-0172-y.

9. Kuehne A, Huschke S, Bullinger M. Subjective health of undocumented migrants in Germany - a mixed methods approach. BMC Public Health. 2015;15:926. doi:10.1186/s12889-015-2268-2.

10. Wenner J, Rolke K, Breckenkamp J, Sauzet O, Bozorgmehr K, Razum O. Inequalities in realised access to healthcare among recently arrived refugees depending on local access model: study protocol for a quasi-experimental study. BMJ Open. 2019;9:e027357. doi:10.1136/bmjopen-2018-027357. 
11. Ledoux C, Pilot E, Diaz E, Krafft T. Migrants' access to healthcare services within the European Union: a content analysis of policy documents in Ireland, Portugal and Spain. Global Health. 2018;14:57. doi:10.1186/s12992-018-0373-6.

12. Reyes-Uruena JM, Noori T, Pharris A, Jansà JM. New times for migrants' health in Europe. Rev Esp Sanid Penit. 2014;16:48-58. doi:10.4321/S1575-06202014000200004.

13. Huepers A, Taddese HB, Filippidis FT. European Union citizens' views on development assistance for developing countries, during the recent migrant crisis in Europe. Global Health. 2018;14:61. doi:10.1186/s12992-018-0378-1.

14. Suphanchaimat R, Kantamaturapoj K, Putthasri W, Prakongsai P. Challenges in the provision of healthcare services for migrants: a systematic review through providers' lens. BMC Health Serv Res. 2015;15:390. doi:10.1186/s12913-015-1065-z.

15. Tyrberg M. Immigrants' electoral participation - the cross-national impact of public and political hostility. J Ethn Migr Stud. 2019;1-25. doi:10.1080/1369183X.2019.1601548.

16. Kerimova MM. Migration crisis in the Republic of Slovenia, 2015-2016: ethno-cultural aspect. Sib Hist Res. 2018;256-77. doi:10.17223/2312461X/22/13.

17. Malešič M. The securitisation of migrations in Europe: the case of Slovenia. Theory Practice. 2017;54:947-68 (https://www.researchgate.net/publication/322328295_The_securitisation_of_migrations_in_Europe_The_case_of_Slovenia, accessed 10 August 2019).

18. United Nations. Universal declaration of human rights, 1948. (https://www.un.org/en/universal-declaration-human-rights/, accessed 10 August 2019).

19. Dancygier RM, Laitin, D. Immigration into Europe: economic discrimination, violence, and public policy. Annu Rev Polit Sci (Palo Alto). 2014;17:43-64. doi:10.1146/annurev-polisci-082012-115925.

20. Kolar D. Odnos državljanov Republike Slovenije do migracij in migrantov: primerjava stališč leta 2007 in 2017: magistrsko delo [Attitudes of citizens of the Republic of Slovenia on migration and migrants: comparison of views in 2007 and 2017: masters thesis]. Ljubljana: Univerza v Mariboru, Fakulteta za varnostne vede [University of Maribor, Faculty of Security Sciences], 2017 (https://dk.um.si/IzpisGradiva.php?id=68384\&lang=slv, accessed 9 July 2019).

21. Šalamon NK. The principle of solidarity in asylum and migration within the context of the European Union accession process. Maastrich J Eur Comp Law. 2017;24:687-702. doi:10.1177/1023263X17742814.

22. Robida A. Nacionalna anketa o izkušnjah pacientov v bolnišnici [National survey on patient experience in hospital]. Ljubljana: Ministrstvo za zdravje Republike Slovenije [Ministry of Health of the Republic of Slovenia], 2007 (http://www.mz.gov.si/fileadmin/mz.gov.si/pageuploads/mz_dokumenti/delovna_podrocja/zdravstveno_varstvo/kakovost/anketa_kakovosti_pacienti_2006/ NAIP_2006_Bol_Celota_splet.pdf, accessed 9 July 2019).

23. Repolusk A. Zadovoljstvo uporabnikov zdravstvenih storitev osnovnega zdravstva na primarni ravni: magistrsko delo [Customer satisfaction of primary health care services: master's]. Celje: Mednarodna fakulteta za družbene in poslovne študije [International Faculty of Social and Business Studies], 2013 (https://plus.si.cobiss.net/opac7/bib/12372897, accessed 9 July 2019).

24. Cencič M, Čagran B, Ivanuš-Grmek M. Kako poteka pedagoško raziskovanje: primer kvantitativne empirične neeksperimentalne raziskave [How pedagogical research is conducted: an example of quantitative empirical non-experimental research]. Ljubljana: Zavod RS za šolstvo [Institute of the Republic of Slovenia for Education]; 2009 (https://www.worldcat.org/title/kako-poteka-pedagosko-raziskovanje-primer-kvantitativne-empiricne-neeksperimentalne-raziskave/oclc/449618343, accessed 9 July 2019).

25. World Medical Association. Declaration of Helsinki - ethical principles for medical research involving human subjects, 2018 (https://www.wma.net/policies-post/wma-declaration-of-helsinki-ethical-principles-for-medical-research-involving-human-subjects/, accessed 9 July 2019).

26. Medica K, Kralj A, Simčič B. Raziskava o ekonomskih migracijah in delavcih migrantih [Survey on economic migration and migrant workers]. Ljubljana: Univerza v Ljubljani, Fakulteta za družbene vede, Arhiv družboslovnih podatkov [University of Ljubljana, Faculty of Social Sciences, Social Data Archive]; 2012 (https://repozitorij.upr.si/IzpisGradiva.php?id=1664, accessed 23 July 2019).

27. Potič Z, Pribošič M. Anketa Dela: večina za ostre ukrepe proti prebežnikom [Labour poll: majority for tough measures against defectors]. 2016 (https://www.delo.si/novice/slovenija/anketa-dela-begunska-kriza.html, accessed 23 July 2019).

28. Štrok L. Javno mnenje o migrantih in beguncih v Republiki Sloveniji: diplomsko delo [Public opinion on migrants and refugees in the Republic of Slovenia: thesis]. Ljubljana: Univerza v Mariboru, Fakulteta za Varnostne Vede [University of Maribor, Faculty of Security Sciences]; 2016 (https://dk.um.si/IzpisGradiva.php?id=62489, accessed 23 July 2019).

29. Zupanc Tergalv B, Selak Š, Vrdelja M, Kaučič BM, Gabrovec B. Patient satisfaction with the level of being informed about the changes in Slovenian healthcare system. Nursing in the 21st Century. 2019;18:37-41. doi:10.2478/pielxxiw-2019-0003

30. Eurobarometer: Public Opinion in the European Union. Integracija priseljencev v Evropski uniji [Integration of immigrants in the European Union]. Brussels: European Commission; 2016 (https://ec.europa.eu/commfrontoffice/publicopinion/index.cfm/ Survey/getSurveyDetail/instruments/SPECIAL/surveyKy/2169, accessed 20 September 2019).

31. Eurobarometer: Public Opinion in the European Union. Javno mnenje v Evropski uniji: nacionalno poročilo - Slovenija [National report - Slovenia]. Brussels: European Commission; 2018 (https://ec.europa.eu/commfrontoffice/publicopinion/index.cfm/Survey/getSurveyDetail/instruments/STANDARD/surveyKy/2215, accessed 20 September 2019). 